\title{
Filozof, Şah ve Ayetullah: Foucault ve İran Devrimi
}

Sever Işık*

Öz

İran Devrimi sırasında yaşananları yerinde gözlemleyen Foucault, siyasi maneviyatın motive ettiği kitlesel gösterilerden derinden etkilenir. Düşüncesinden izler taşıması sebebiyle Foucault'nun devrime duyduğu ilgi tek sebebe indirgenemez. Foucault, devrimin dinamiği olan siyasi maneviyat1 yeni bir politik tahayyül açığa çıkışı olarak görmüştür. Söz konusu siyasi maneviyat modern siyasi düşüncenin aşina olmadığ yeni bir politika yapma tarzı ve öznellik inşa sürecidir. Dini ve siyasi olanın bir diğeri içinde çözüldüğ̈̈ İran Devrimi, Batı politik rasyonalizmin sınırına işaret etmekte, farklı bir düşünce ve eyleme tarzının mümkün olduğunu göstermektedir. Batılı perspektiften anormal/akıldışı olan devrim total bir red ve direniş hareketidir. Müşterek iradeyi açığa çıkaran devrim ayrıca liner, teleolojik tarih tasavvuruna açıkça bir meydan okumadır. Çatışma ve uzlaşmayı esas alan sağ ve sol devrim modellerinin uymayan İran Devrimi yeni bir öznellik ve etik inşasını beraberinde getirmiştir. Devrim dinamiği oluşturan siyasi maneviyat onun tekilliğini ve ayrıcalığını oluşturmaktadır. Gerçekte devrimin özünü oluşturan yeni öznellik, etik ve benlik teknolojileri İslami bir kısım ilke ve pratiklerin Foucaultçu dile tercümesidir.

Anahtar Kelimeler: Devrim, İsyan, İslam, Siyasi Maneviyat, Öznellik, İran

* Dr, MEB, severquista@gmail.com 


\title{
Philosopher, Shah and Ayatollah: Foucault And Iran Revolution
}

\author{
Sever Işık*
}

\section{Abstract}

Foucault, who observed what happened during the iran revolution, was deply impressed by mass demonstration motivated by political spirituality. Foucault's interest to revolution can not be reduced to a dingle reason because it has parts of his philosophy. Foucault sees political spirituality is a come out of political imagination. Political spirituality is a construction process of a new political style and subjectivity which modern political thought hasn't been familiar to, İslamic revolution, which religion and politic disintegrate one another, points to west political rationalism and shows that different thinking and acting are possible revolution which is abnormal and non-intellectual from Western perspective is an total rejection and resistance movement.Revolution that revelals the common will is olso a challange to the linear, teleogical history concept. Iran Revolution which doesn't fit right and left revolution pattern based on confliction and reconcilition, brought a new subjectivity and ethic construction with it. Political spirituality generates singularity and privilage of revolution. In reality new subjectivity, ethic and self technologies which generate the core of revolution is the translation of Islamic principles and practices in Foucault way.

Keywords: Revolution, Rebellion, Islam, Political Spirituality, Subjectivity, Iran

* Dr, MEB, severquista@gmail.com 


\section{Giriş}

Batılı bilgi sistemlerinin arkeologu ve iktidarın soykütükçüsü Foucault, 1978'de İran'da şah yönetimine karşı başlatılan gösterileri bizatihi gözlemlemek üzere İtalyan gazetesi Corriere Della Sera adına İran'a giderek isyan ve devrim pratiğini bizatihi gözlemler ve bir dizi makale yayınlar. ${ }^{1}$ Kitlelerin şahın ordusuyla ilk defa karşı karşıya geldiği ve çok sayıda kişinin hayatını kaybettiği Kara Cuma'dan (8 Eylül) sonra İran'a varan filozof ölümü cesurca karşılayan kitlelerin maneviyatından derinden etkilenir. Çoğu İtalyanca bir kısmı ise Fransızca olarak kaleme alınan devrime ilişkin yazılarda Foucault, şahit olduğu bu yeni fenomen karşısında duyduğu şaşkınlığı ve coşkuyu gizle(ye)mez. İsyanı yücelten ve devrimin dinamiklerini olumlayan yorumlarıyla Batı entelektüel kanonunu şaşkınlığa uğratan filozof, yine hiç kimsenin tanımadığı bir "maske" ile yazmıştı. "Şimdinin tarihçisi" Foucault, devrim sürecine dair gözlemleri, devrimci eylem ve öznelere dair "eleştirellik"ten çok "beğeni”"nin hakim olduğu yazıları sebebiyle özellikle devrim sonrası dönemde öngör(e)mediği bir İslami hükümetin kurulması, bu hükümetin bazı muhalifleri ve toplumsal kesimleri tasfiyeye girişmesi Fransa'daki özellikle sol kökenli bazı muhalif aydınların eleştiri oklarını Foucault'ya yöneltmesine sebep olmuştur. Bir kısmı erken tarihte dile getirilmiş bu eleştirilerde filozof, İran' da yaşanan olayların gerçek mahiyetinden bihaber olmakla, totaliter eğilimli bir İslami hükümet olasılığını fark etme konusunda kör ve naif olmakla suçlanır. ${ }^{2}$ Çoğu devrim sonras1 yaşananlardan, dolayısıyla filozofun bir gazeteci olarak gözlemlemiş olamayacağı olgulardan hareketle geçmişe doğru işleyen, filozofu yargılayan ve bazen de mahkum eden bu eleştireler bazı haklı noktalar içermekle birlikte Foucault'nun devrimde gördüğü “tekillikler"i, “doğuşlar”, "oluş"u ve "stratejik olmayan etiği”ni büyük ölçüde gözden kaçırmaktadır.

Foucault, devrime öncülük eden ulemanın devrimin zaferini müteakip kurulacak bir yönetimde gözetleme vazifesiyle yetineceği ve formel bir İslami hükümet kurulmayacağı öngörüsünde yanılmıştır. Gerçekte geleceği öngörmek açısından felsefi bilgi ve müşahedenin filozofa herhangi bir ayrı-

Foucault, 28 Eylül 1978 ile 11 Mayıs 1979 tarihleri arasında 9'u İtalyan, 5'i Fransız gazetelerinde toplam 15 yazı kaleme almış, Claire Bribe ve Pierre Blanchat ile bir mülakat gerçekleştirmiştir.

2 Janet Afary \& Kevin B. Anderson, Foucault ve Iran Devrimi: Toplumsal Cinsiyet ve İslamcılığın Ayartmaları, (Çev. Mehmet Doğan), İstanbul: Boğaziçi Universitesi Yayınevi. 2012, s. 125-126, 295, 309 
calık ve üstünlük sağladığı söylenemez. Gerçi göz kamaştırıcı felsefi müktesebatına rağmen geleceği öngörmekte yanılmıș olmak hususunda Foucault ilk örnek değildir ve muhtemelen son da olmayacaktır. Bu nedenle öngörememe şeklindeki bir yanılgıyı merkeze alan ve geçmişe doğru işleyen eleştiriler Foucault'yu ırgalamayacaktır; zira o amacının ne geçmişin ne de geleceğin tarihini yazmak değil, bugünü anlamak olduğunu defaatle ifade etmiştir; "geleceğin tarihini yazamam, üstelik geçmişi öngörme konusunda beceriksizim. Yine de, tam şimdi ne olup bittiğini kavramaya çalışıyorum, çünkü bu günlerde hiçbir şey bitmiş değil ve zarlar halâ atılıyor. Belki de gazetecinin işi budur, fakat bu işte acemi olduğum da gerçek." ${ }^{3}$

Ne var ki eleştirmenlerin Batı kültürüne meydan okuyuşun "işaret"ini başka bir coğrafyada bulan filozofun yanılgısını yakalamanın (aslında kendilerinin doğrulandığının kibriyle) sevinciyle abartıya kaçmaları onun bir "işaret”e ilişkin yorumlarının değerini iskalamaktadır. Açık olan şey şu ki onun devrimin/isyanın kendisiyle açığa çıkan şey hakkındaki gözlem ve tanıklığ1, mollaların egemen olduğu dini bir yönetim ihtimalini öngörmemesi yanılgısından daha derin bir gerçeği yansıtmaktadır. Foucault'nun yaptığ şey aksiyomatik ve mahkum edici oryantalist klişe ve kategorileri büyük ölçüde aşarak Batı'nın dışında zuhura gelen modernliği aşma imkanı içeren olumsal bir fenomeni anlamaya ve kavramsallaştırmaya çalışmaktır. Bunun içindir ki Foucault'un analizi bugün halâ ilgi çekmekte ve bu devrim analizi dinin dinamiğini oluşturduğu (Arap Baharı vb.) devrimci oluşumları mahkum etmeyi değil, içsel bir analizini mümkün k1lmaktadır.

Hiç şüphesiz yakın zamanda kendisine eleştiri yönelten eleştirmenlerinin de haklı olarak ifade ettikleri gibi Foucault'nun devrim(de) ve İran'da yaşananın olayın doğasına ilişkin yorumları salt gazeteci merakına istinat eden aceleci yorumlar olmayıp, uzun süreli entelektüel ilgileri ile sıkı bir şekilde ilişkilidir. O, devrime sadece bir gazeteci ve aktivist olarak değil, bir kısım teorik kavrayışlarının kısmi doğrulanmasını gören bir filozof olarak yaklaşmıştır. ${ }^{4}$ Dolayısıyla devrim onun için sadece politik değil, felsefi ve bir o kadar da etik öneme sahipti. Geçmiş çalışmaları devrime dair yorumlarını çerçevelediği gibi devrim de Foucault'nun son dönem ilgile-

Foucault, "İran Ayaklanmasının Efsanevî Önderi”, Janet Afary \& Kevin B. Anderson, Foucault ve Iran Devrimi: Toplumsal Cinsiyet ve İslamcılı̆̆ın Ayartmaları içinde, s. 280

4 Janet Afary \& Kevin B. Anderson, s. 17, 55; "Michiel Leezenberg, Michel Foucault on the Islamic Revolution in Iran". In Cultural History after Foucault, edited by J. Neubauer. New York: Transaction Publishers, 1999. 
rini yönlendirmiştir. Gerçekte Foucault'nun devrime dair yorumları hem arkeolojik, hem soykütükçü hem de etik çalışmaları çerçevesinde okunup yorumlanabilecek mümbit bir muhtevaya sahiptirler. Bu perspektiften bakıldığında $\mathrm{o}$, bir taraftan devrimde modernliğin artık sınırlarına dayanmış rasyonel/normal Batı aklına nispetle (ki yaşamını bu akılın sınırlılığını, tarihselliği göstermek ve tahakkümünü kırmaya çalışmakla geçirmiştir) Batı dışı bir bilgi sistemine istinat eden bir epistemik ötekiyi/anormali görüp, devrimi "İran'ın deliliği”’5 (The Madness of Iran/'La folie de l'Iran) olarak konumlandırırken, diğer taraftan sokaklara dökülen kitleler ile bu kitlelerin arzuları ve onları yönlendirenler arasında farklı türden bir iktidar/direniş ilişkisi görmüş ve bunu yeni bir öznellik türünün tarihe dahil oluşu olarak değerlendirmiştir. Devrimin önemli bir etken olduğu yeni etik merkezli felsefi güzergahında Foucault, dışsal bir iktidar değil, yeni bir öznelliğin oluşumunu mümkün kılan nefs/benlik teknolojilerinin ürettiği içsel bir iktidar analizine yoğunlaşmıştır. Bu sebeple onun etik ve politik olanın iç içe geçtiği bu devrime ilişkin felsefi okuması tekil bir perspektife kapatılamaz. Foucaultcu analiz onu bir noktaya indirgemeye ve sabitlemeye çalışan sabit ve tekil okumalara daima meydan okur. Onun devrime ilişkin yorumları tüm felsefi güzergâhlarından izler taşır.

$\mathrm{Bu}$ yazı da öncelikle Foucault'nun devrimde gördüğü ve olumladığ şey(ler)i ortaya koyarak bunu felsefi güzergahları ile ilişkilendirmeye çalışacak, son noktada ise onun bir tür "yaşantı" olarak gördüğü ve devrimin künhünü oluşturduğunu düşündüğü nefs pratiklerinin ve öznellik inşasının, dinsel olan ile politik olanın bir diğerinin içinde çözülmesinin, her birinin diğerini mecz etmesinin ve yine onun İslami hükümete dair düşüncelerinin, daha doğrusu halkın İslami hükümet ile muradının muhtemelen çoğunu yine devrime ilişkin soruşturma ve araştırmasını yaparken aşina olduğu İslami olan bir kısım ilke ve değerlerin Foucaultcu dile tercümesi olduğunu iddia edeceğim. Devrime ilişkin soruşturmasında büyük ölçüde devrimi yaşayanların bilincine ve benlik algısına sadık kalan filozof, “öteki”ne kulak kesilirken açıkça eleştirinin dozunu epeyce düşürür.

Bu yazının başlığındaki filozof, şah ve ayetullah devrimin özneleri olan birer gerçek kişilik kadar birer metafor/imge olarak farklı, fakat daima ilişkili

\footnotetext{
Dits et ecrits editorlerine göre Corriere Della Serra'da, 26 Kasım 1978'de yayınlanan “İran Ayaklanmasının Efsanevî Önderi” başlıklı yazısına Foucault’nun önerdiği başlık “İran'ın Deliliği” idi. Bkz. Janet Afary \& Kevin B. Anderson, s. 280.
} 
olan daha büyük olgu ve anlam dünyalarını temsil etmektedir. Bu sebeple yazının başlığ 1 gönderimleri itibarıly en geniş anlamda felsefe, iktidar ve din (düşünce, devlet ve din) olarak da okunabilir. Şah ve ayetullahın gerçek tarafları olduğu bir mücadele de filozof yaşananların tanığı konumundadır. Dinin siyasi olanı askıya aldığı bir mücadelede o, pasif bir izleyici değil, aktif bir gözlemcidir/tanıktır. Foucault'nun devrim "defter"inde ${ }^{6}$ şahın şahsında Batı modernleşmesine, onun etosu olarak gördüğü Aydınlanma' ya ve devlete (akıl ve iktidara) yaklaşımını; Humeyni'nin “mistik lider'liği ve göstericilerin siyasi maneviyatında ise öznellik üreten bir etik kaynak olarak dine dair yorumlarını görüyoruz.

Konuya girmeden önce konunun daha sağlıklı anlaşılması için Foucault'nun 'devrim' kavramına ve kavramı kullanımına değinmek yararlı olacaktır. Hiç şüphesiz Foucault için devrim Avrupa'nın politik tarihi ve pratiği içerisinde anlamlandırılmış, içeriklendirilmiş modern bir kavramdı. Dolayısıyla kavram kullanıldığı zaman genel olarak (ister Marksist ister liberal olsun) modernliğin içinde kalan, Hegelyen anlamda ilerici bir devinim ve gaye içeren bir değişim formunu ifade etmek amacıyla kullanılmaktaydı. $\mathrm{Bu}$ seküler mesihçi ve eskatolojik karakterine karşın modern dönemde vuku bulan devrimler tüm şatafatlı retorik ve iddialarına rağmen iktidar pratiklerinin sahici bir değişimine değil, ancak siyasal iktidarın ele geçirilmesine yönelmişlerdir. $\mathrm{Bu}$ anlamıyla Batı tarihine ait olup, Marksizm tarafından temellük edilmiş güncel anlam içeriği ve pratiği sebebiyle kavram onun nazarından pek olumlu ve radikal bir içeriğine sahip değildir. Zira politik olarak tanımlanan söz konusu modern devrimler, modern episteme içinde kaldıklarından gerçek anlamda bir epistemik ve politik kopmay $1 /$ kırılmayı ifade etmezler. Foucault, iktidarı elde etme amacina matuf politik bir program olan devrimleri kesinlikle onaylamaz. Bu sebeple onun için asıl politik eylem devrim değil, isyandır. Devrim/ler iktidara odaklanırken, isyanlar/ ayaklanmalar iktidara sınır çizerler ve bir "program"dan çok bir "oluş"u ifade ederler. Foucault'nun kendisine yöneltilen eleştirilere yönelik cevabi yazısının başlığının “Ayaklanma Faydasız mı?” başı̆̆ğını taşıması bir rastlantı değildir. Bununla beraber Foucault, devrim kavramını kullanır; fakat kullandığı bağlama ve ona yüklediği anlama bakmak gerekir. O, devrimi bir politik program olarak değil, yeni bir politik tahayyül ve politika yapma

Corriere Della Sera'daki yazı serisine editörün koyduğu başlık "Michel Foucault: Foucault'nun Defteri"ydi. 
tarzının, yeni bir öznellik türünün (varoluş tarzının) oluşumu olarak olumlamıştır.

\section{2. İran ve Devrim: Sahne ve Gösteri ya da 'Çıplak Elli Adamların Devrimi'}

Kendisini "şimdiki zamanın tarihçisi”, dolayısıyla bir gazeteci olarak tanımlayan filozof Foucault, Eylül 1978'de İran'a vardığında şah karşıtı gösteriler tüm hızıyla devam etmekte, ülke şah karşı gösterilerle çalkalanmaktaydı. Onun varışından kısa bir süre önce halk şahın ordusuyla karşı karşıya gelmiş, ordunun göstericilerin üzerine ateş açması sebebiyle binlerce kişi hayatını kaybetmiş fakat tüm bu ölümler göstericilere geri adım attıramamış ve göstericiler yaşamlarını kaybetme pahasına gösterilere yoğun bir katılım göstermişlerdi. Açıkça Foucault için İran, bütün bir halkın rol aldığ 1 bir devrim sahnesine dönmüştü. Gerçek bir devrimin sahnelendiği, iktidarın yaşam ile sınırlandığ bu trajik devrim gösterisinde filozofu büyüleyen ve devrimci olayı karakterize şey, politik felsefenin tanıdığ olan "müşterek irade"nin ortaya çıkmış olmasıydı. Foucault, Tahran ve İran'ın dört bir yanında Tanrı gibi, ruh gibi her zaman karşılaşılamayacak bir şey olduğunu düşündüğü, hukukçuların ve filozofların kurumları analiz etmek veya haklılaştırmak için kullandıkları "siyasi bir mit" olan müşterek irade ile karşılaşmış ve onu selamlamıştır. Her zaman karşılaşılamayacak bir şey olan bu müşterek irade İran'da "tarihin içinden patlayarak ortaya çıkmış" ve tek bir hedefe yönelmiştir: Şahın gitmesi. Foucault için tüm bir ulusun bu kolektif, uzlaşmaz ve total ret edişinin derin bir anlamı vardır. $\mathrm{Bu}$ "köktenci ret ediş" sadece şahın ve onun temsilcisi olduğu yabancıların (Batı müdahaleciliğinin) değil, bir halkın "yüzyıllarca siyasi yazgısını oluşturmuş olan her şeyi reddidir."” Şah Yüzyıl Geride Kaldı başlıklı yazısında bu reddin içeriğini daha açık bir şekilde ortaya koyan filozof, açıkça şahın totaliter yönetimini, onun icra ettiği cebri modernleşme projesini, tüm bunların sebebi ve aynı zamanda sonucu olan çürümüşlüğü bir bütün olarak değerlendirir. İşte sokaktan yükselen bu köktenci ret, en genel anlamıyla aslında yüzyıl geriden gelen modernleşmenin reddidir. Burada Foucault'nun arkeolojilerinde ve soy kütüklerinde modernliğin daima disiplinler olan ile birlikte anıla geldiğini hatırladığımızda bu reddedişin Foucault açısından ne denli olumsal bir ret ediş olduğu daha iyi anlaşılır. Onun için modern

\footnotetext{
Foucault, "İran: Ruhsuz Dünyanın Ruhu”, Tezkire, Sayı: 2, Şubat-Mart 1992, s. 83
} 
toplum/dünya görülmeden gözetleme ve kontrol ilkesinin işlediği bir çeşit hapishaneydi/“panoptikon"du. Hapishaneden kaçıș düșüncesi her zaman Foucault'yu büyülemişti. Sadece mecazen değil, hakikaten... ${ }^{8}$

Kendisini derinden etkilese de Foucault, soyut bir kavram olarak müşterek irade kavramına zaten aşinaydı. Müşterek iradeyi onun için bunca anlamlı kılan şey, bu iradenin, devrimin sınıfsal çelişki taşımayan bütüncül karakterini imlemesiydi. Batılı modern devrim kuramlarının aşina olmadığı bu "çelişkisizlik" ve "bütünsellik" durumu devrimi teorik açıdan "yabancı" ve "kuraldışı", dolaysıyla "anormal" kılmaktaydı. Devrim ne bir çelişki dinamiğini esas alan Marksist ne de bir uzlaşımı esas alan liberal modele uymamakta, her iki siyasal perspektiften anti teorik bir karakter taşımakta dolayısıyla açıklan(a)mazlık ve anlaşı1(a)mazlık arz etmektedir ki o, bu durumu sarahatle dile getirir. Çünkü der Foucault:

"Şimdi biz bir devrimi ancak şu iki dinamiği gözlemleyebildiğimiz zaman kabul ediyoruz. Biri sınıf çatışmasından veya toplumsal karşıtlıklardan kaynaklanan çelişkiler dinamiği. Diğeri ise politik bir dinamiktir. Yani bir öncünün sınıf parti veya siyasi ideolojinin kısaca bütün ulusu kendisi ile taşıyacak bir bayrağın varlığı. Şimdi ise bana öyle görünüyor ki İran'da olan bitende bize göre devrimci bir olgunun ayırt edici işaretleri ve açık görüntülerini oluşturan bu iki dinamiğin hiçbiri görülemez. Bir toplumun içsel çelişkilerin yerleştirilemediği ve bir öncüye işaret edilemediği devrimci bir hareket bize göre nedir?"'

Söz konusu devrim Marksist kuramda olduğu gibi herhangi bir sınıfın değil, tüm bir halkın devrimiydi. Dolaysıyla sol bir model içerisinde kalınarak devrimi anlamak mümkün değildi. Burada erken bir tarihte İran Devrimi'ndeki öznelliği ve kendine has devrimci maneviyatı keşfeden ve devrime dair coşku yüklü yorumlarda bulunan Foucault'nun devrime ilişkin yorumlarında hesaplaşılan karşıt bir figür olarak Marks, model olarak ise Marksizmin önemli bir yer işgal ettiğini daima hatırda tutmak gerekir. ${ }^{10}$ Bu sebeple onun devrime ilişkin yorumlarında Marksist literatüre yoğun bir atıf vardır.

8 Ona göre mahkûmların ilk görevi kaçmaktı. Bkz. "İdeal Adalet Mi, Sınıf Mücadelesi Mi?" (Michel Foucault - Noam Chomsky Söyleşisi), Michel Foucault, Kendini Bilmek içinde, (Çev. Gül Çağalı Güven), İstanbul: Om Yayınevi, 1999, s. 154-159.

9 Foucault, “İran: Ruhsuz Dünyanın Ruhu”, s. 81.

10 Sever Işık, "Michel Foucault'nun Marksist Tarih, İktidar ve İdeoloji Eleştirisi”. Birey ve Toplum, Cilt 1, Say1 1, 2011, s. 133. 
O, bir yerde devrime Marksist epistemolojinin sınırlılığının aktüel nişanesi olarak bakar. Marksist-Leninist devrim kuramında olduğu gibi ne bir sınıf çatışmasının ne de devrime öncülük eden bir sınıf ve parti örgütlenmesinin söz konusu olmadığı İran, genelde anti-modern özelde ise anti Marksist bir laboratuvardı. İslamın devrimci dinamiğini açıkça olumlayan filozof yine olumsuzlayıcı bir tarzda Marksizme gönderimde bulunarak devrimin gerisindeki dini motivasyonun Marksistlerin coşku ile vaaz ettikleri "ideolojik yanılsama" olmadığını vurgular. ${ }^{11}$ Dinin devrimdeki rolünü ifade eden ve devrimi tanımlamaya çalışan en ünlü yazılarından birinin başlığ şekilde Marks'ın dine dair sıklıkla anılan ve alıntılanan "kalpsiz dünyanı kalbi" sözüne atfen "ruhsuz dünyanın ruhu" başlığını taşıması son derece anlamlidir.

“Tahran: Şaha Karşı İnanç” yazısında aynı üslupla aynı yerden yüklenmeye devam eder: "İranlıların en çok dudak büktüğü, onlara en aptalca, en sı ğ görünen ifadenin ne olduğunu biliyor musunuz? "Din halkların afyonudur." Mevcut hanedanın devrine kadar, mollalar camilerde vaaz verirken yanlarında ateşli silah bulundururdu". ${ }^{12}$ Almond'un ifade ettiği gibi onun bu satırlarında afyonun etkisinde olanların öncülük ettiği devrimin Batılı düşünce tarihinin bu en ünlü ve havalı sözünü (belirli bir vakitte, belirli bir yerde söylenmiş bir söze) tarihselliğe indirgemesinden memnuniyet duyulur. ${ }^{13}$ Gerçi Foucault'nun bu tutumu yeni değildi. O, modernliğin bir tezahürü olarak erken bir tarihte Marksizme karşı konumlanmış ve Marksistlerin canını epeyce sıkacak bir şekilde Marksizmin, Batı bilgisinin derin düzeyinde hiçbir gerçek kopuş meydana getirmediğini, 19. yüzyılın epistemolojik düzeninin içine hiçbir güçlük çıkarmadan yerleşebileceğini ve 19. yüzyılın düşüncesinde, tıpkı sudaki balık gibi olduğunu, onsuz hiçbir yerde nefes alamayacağını ${ }^{14}$ ifade ederek tarihsel sınırlılığını ve teorik sınırlarını ortaya koymuş, Kelimler ve Şeyler'de ifade ettiği ölmekte olan modernliğin epistemesinin içine yerleştirmiştir. Devrim, modernliğin alt ettiğini iddia ettiği farklı bir anlam dinamiğine dayanmaktaydı. Dolayısıyla onun anlamak ve çözümlemek için modernliğin dışında farklı kavramsal alet ve

11 Foucault, “İran: Ruhsuz Dünyanın Ruhu”, s. 80.

12 "Tahran: Şaha Karşı İnanç", Janet Afary \& Kevin B. Anderson, Foucault ve İran Devrimi: Toplumsal Cinsiyet ve Íslamcılı̆̆ın Ayartmalarl, (Çev. Mehmet Doğan), İstanbul: Boğaziçi Üniversitesi Yayınevi, s. 256.

13 Almond, s. 18.

14 Foucault, M. Kelimeler ve Şeyler/ Insan Bilimlerinin Bir Arkeolojisi, (Çev. M. Ali Kılıçbay), Ankara: İmge Kitabevi, 1994, s. 367. 
edevata ihtiyaç vard1.

Foucault açısından olan biteni anlamak ve anlamlandırmak konusunda liberal model Marksizm karşısında herhangi bir ayrıcalığa sahip değildi. Devrim, Batılı/modern Marksist modele uymadığ 1 gibi liberal bir modele de uymamaktaydı. Yukarı da belirttiğimiz gibi sonsuz ve köklü bir red ediş üzerine temellen devrim, çıkarların uzlaştırılması/maksimizasyonu vb. herhangi bir liberal içerik ve arzu da taşımıyordu. Kendi ifadesiyle; "şahit olduğumuz şey değişik guruplar arasındaki bir ittifakın sonucu değildir. $\mathrm{Bu}$ sosyal sınıflar arasındaki, şu veya bu konuda her birinin bir taviz vermesiyle veya bu iddia ve talepte hemfikir olmalarının sonucu da değildi". ${ }^{15}$ Liberal, yasal normatif bir modele dayanmayan devrim, Fransa 1968'de olduğu gibi devletin baskıcı kurumlarından kurtulmaya dönük liberal bir arzu da taşımıyordu. Devrimin evvel emirdeki amacı politik yaşamda İslami toplum yapısına yer vermekti1 ${ }^{16} \mathrm{ki}$ bu Batılılar için epeyce yabacı bir şeydi.

İslami siyasi maneviliğin şekillendirdiği devrimi betimlemek için Foucault'nun özenle kullandığı, "sahne" kavramı ile ilişkili bir diğer kavram ise "gösteri"dir. Bu kavram daha önce kullandığ 1 "trajedi" ifadesi ile bir arada okunmalıdır. Şahın tahtı bırakmaya mecbur eden sonsuz bir ret içeren bu gösteride müşterek eylem, dinsel inayet ve kamusal hakkın ifadesi arasında bir bağ vardır. Foucault, "müşterek ayin”, kollektif seremoni ile hak ilkelerinin yeniden kabulü ve eyleme geçirilişinin beraber yürüdüğü” bu gösteriyi Yunan trajedilerine benzetir. "Tahran caddelerinde bir eylem, siyasi ve hukuki bir eylem vardır. Topluca dinsel ritüellerle tamamlanan bir hükümdarı tahtan indirme eylemi." ${ }^{17}$ Açıkça devrim bir çeşit ibadet, dini ritüel (ve tabii ki gösteri) olarak yaşanmaktadır. Çünkü,

"Herkesin hayatı ile kumar oynadığı, tarih içi ve tarih dışı o an, ayaklanmalar kendi ifadelerini, dramaturgilerini kolaylıkla dinsel bir biçimde bulur. $\mathrm{Bu}$ bir ideolojik kılıf olmayıp yüzyıllar boyunca ayaklanmaların yaşam biçimini meydana getirdi. ${ }^{18}$....Ayaklanmacıların rejimden nefreti, rejimi devirme istekleri, yani istekleri siyasi olduğu kadar dini ve düşseldi. Ordunun ölüm

15 Foucault, "İran: Ruhsuz Dünyanın Ruhu", s. 86.

16 Foucault, “İranlılar Ne Düşlüyor?”, Janet Afary \& Kevin B. Anderson, Foucault ve Iran Devrimi: Toplumsal Cinsiyet ve İslamcılı̆̆ın Ayartmaları içinde, s. 263.

17 Foucault, "İran: Ruhsuz Dünyanın Ruhu", s. 84.

18 Foucault, “Ayaklanma Faydasız mı?”, Entelektüelin Siyasi İşlevi içinde (Çev. Işık Ergüden, Osman Akınhay, Ferda Keskin), İstanbul: Ayrıntı Yayınları, 2011, s. 298. 
tehdidini felç eden isyancılar ona karşı dinsel törenlerin ritmi ile hareket ediyor ve iktidarın her zaman lanetli olduğu zaman dışı bir dramaturgiye başvurabiliyorlardı. ${ }^{19}$

Bu siyasi/dini gösterinin muhtevasını şekillendiren şehadet söylemi, adanmışlık, bedensel ritüeller, Şii kefaret kültü Foucault'yu hayran bırakmışt. Milyonların iştirak ettiği bu gösteri onu büyülemişti. İslam, "halkı hem krala ve polise karşı hem de bütün bir rejime, bütünüyle bir hayat tarzına, bütün dünyaya karşı" ayaklandıran "gerçek bir güç"tü.. ${ }^{20}$ Tüm bir halkın müşterek iradesinin makineli silahlarla karşı karşıya geldiği bu isyan "çıplak elli adamların isyanı"ydı/devrimiydi ${ }^{21}$. Devrimin açığa çıkardığı coşku ve tikellik Foucault'yu şaşırmış olsa da Batılıların devrimi anlamamasında Foucault'yu şaşırtacak bir şey yoktu. Çünkü hem sol hem de liberaller 19. yüzyılın aklı ile düşünmekteydiler. ${ }^{22}$ Batılıları ürküten ve endişelendiren devrimin bu dini ritmiydi. Bu konuya daha sonra tekrar döneceğiz.

\section{Fikirlerin Patlaması ve Zamanda Yarılma}

İran Devrimi'nin en sıra dışı yanı Batı dışı bir toplumdan meydana gelmesi, böylece Batılı mekan ve uzamın dışına çıkarak Batılı evrensel zaman anlayışını parçalamasıdır. Foucault'nun dediği gibi devrimci irade "tarihin içinden patlayarak" ortaya çıkmıştır. Kitleler dinsel bir fenomene dayanarak şaha meydan okumaktaydılar. Geride kalması gereken fikirlerin bugün devrim formunda ortaya çıkması ve üstelik Batı destekli modern/leştirici bir monarşiyi alt etmeye girişmesi Hegelci teleolojik tarihte /zamanda bir çatlamayı ve yarılmayı ifade etmektedir. Daha önce ifade ettiğimiz gibi modernlik ile doğrudan ilişkili bir kavram olan devrim, değişim diyalektiğinin ve dinamiğinin işlediği Batı tarihine ait bir olgu olarak görülmektedir. İlerleme kavramı ile birlikte ele alınan bir değişim hareketi, toplumu daha ileriye taşıyan bir dönüşümü ifa ettiği ölçüde devrim olarak addedilmektedir. $\mathrm{Bu}$ tarih ve toplum algısında homojenliğin ve dinginliğin egemen olduğu Doğu'da egemen olan şey yenileme değil, olsa olsa yinelemedir. Devrim

19 Foucault, “Ayaklanma Faydasız mı?”, s. 299.

20 Foucault, "İslam Denen Barut Fıçısı”, Janet Afary ve Kevin B. Anderson, Foucault ve İan Devrimi- Toplumsal Cinsiyet ve İslamcılı̆̆ın Ayartmaları içinde, s. 302.

21 Foucault, "İran Ayaklanmasının Efsanevi Önderi”, s. 283.

22 Foucault bir yazısında 19. yüzyılda sermayenin temerküzü probleminden kaynaklanan ideolojik ve siyasal kavramların 20. yüzyılın iktidar aşırılığı problemini izah etmekte yetersiz kaldığından yakınmıştı. Bkz. Michel Foucault, "İktidar ve Bilgi”, İktidarın Gözü, (Çev. Işık Ergüden), İstanbul: Ayrıntı Yayınları, 2003, s. 169. 
yerinde sayan, geçmişe bakan bir toplumda değil, ancak tarihin ileriye doğru aktığı/devindiği Batı toplumlarında zuhur edebilirdi. Dolayısıyla devrim bizatihi Batılı zamana ve mekâna ait bir şeydi. Batı dışı bir devrim zamanda bir çatlağa ve daha doğrusu bir tarih/zaman dış1lığa işaret eder. Bu sebeple devrimi kendi tarihsel şemalarına uydurmaya çalışan Batılılar onu "arkaik" olarak damgalamaktaydılar.

Foucault ise yaşananları devrim olarak niteleyerek ve olumlayarak açıkça Batılı liner zaman-tarih perspektifini eleştirmiştir. Zira ilhamını 1300 yıl öncesinden alan bir öznelliği Hegelci bir tasavvurla örtüştürmek mümkün değildi. Devrim, tarihsel dinamiğin işlemediği varsayılan İran gibi Batı/ modernlik/akıl dışı bir Doğu toplumunda sürekli ileriye doğru akan ve modernliğin, geçmişte kaldığını, akıl ve bilimin üzerini örttüğünü iddia ettiği dinsel bir motivasyonla vücuda gelmiştir. Bu özelliğiyle devrim bizatihi devrim olgusunun kendisini tartışılır kılmıştır. Çünkü modern dönem boyunca ancak devinen ve ilerleyen Batı toplumların hasredilmiş bir değişim formu olarak görülen devrim, şimdi değişmez ve durgun sayılan Batı dışı bir toplumda vuku bulmuştur. Bu yüzden bu devrimin zamanı Batı'nın zamanı değildir.

Yukarıdaki sebebe binaen Almond'un dediği gibi Foucault'nun yazılar1 geniş anlamda Batılı teleolojileri yıkma amacına hizmet eder ve modern Batılı tarih yazımını bölgeselleştirir (provincializer). ${ }^{23}$ İslam, Batı'nın zamansallığını yerinden eder. Gamari'ye göre'de Foucault'nun devrime ilgisi ve coşkusu Afary'nin iddia ettiği gibi pre-modern değer ve kültürün romantize edilmesinden değil, tarihin Batılı teolojik şemaların d1şında yapılıyor olmasından kaynaklanmaktadır. ${ }^{24}$ Foucault, İran'da şahın temsilcisi ve uygulayıcısı olduğu modernliği "arkaik" olarak niteleyerek ${ }^{25}$ klasik modern/ilerici geleneksel/gerici ikiliğini yerinden ederek klasik oryantalist kategorilerin dışına doğru bir hamle yapar. Devrimi damgalamadığı gibi, dinamiğini olumlar. Onu bilindik Batılı kavramların içine sığdırmaya çalışmaz. Batılıların devrimin faillerine öğretecek bir şeyi ol-

23 Almond, s. 19.

24 Ghamari-Tabrizi, Behrooz. "When Life Will No Longer Barter Itself: In Defense Of Foucault On The Iranian Revolution. " A Foucault for the 21 st Century: Governmentality, Biopolitics and Discipline in the New Millenium, edited by S. Binkly and J. Capetillo içinde. 271-292, New Castle, UK: Cambridge Scholars Publishing, 2012, s. 274.

25 Foucault, "Şah Yüzyıl Geç Kaldı", Entelektüelin Siyasi İşlevi içinde (Çev. Işsık Ergüden, Osman Akınhay, Ferda Keskin), İstanbul: Ayrıntı Yayınları, 2000, s. 293. 
madığını söyler. İslamı, ruh/bilinç ve dinamizm bahşeden bir güç olarak açıkça olumlayan filozof, devrimde oluşa gelen tikelliği Batı'nın kavramlarıyla görmeyi ret eder; gerçekten anlamaya çalışır. Atoussa'nın İslam'ın tüm veçhe ve olanaklarını bir bütün olarak "bin yıllık fanatizm" şeklinde damgalayarak, kendisinin “İslam’ın gerçeğini” görmediği iddiasına karşı çıkan Foucault sözünü sakınmaz: "İslama asgari zeka ile yaklaşmanın ilk koşulu, işe nefret duygusu karıştırmamaktır. ${ }^{26} \mathrm{O}$, devrimdeki rolü itibarıyla dini bir İrani arkaizm formu ya da post kolonyalizmin dini fonksiyonel araçsallaştırma stratejisi (yani ideolojik Makyavelizm) olarak görmeyi ret eder. ${ }^{27}$ Fakat yine de onun İran yazılarında bir gerilim mevcuttur. Bir taraftan Müslüman bir toplumun değişimci ve devrimci dinamiğini olumlayarak şarkiyatçılığın sınırlarını aşarken, diğer taraftan İran toplumunu 1300 yıllık inancını olduğu gibi muhafaza eden, "istikrarlı" bir toplum olarak vasfederken şarkiyatçılığın doğu toplumlarının "statik”liği ve "homojen”liği düşüncesine yaklaşır. ${ }^{28}$ Yine aynı yazılarda "biz Batılılar" çoğul öznesi içinden aidiyet belirterek konuşurken evrensel oldukları iddia edilen Batılı değerleri tarihselleştirmekten de geri kalmaz. Böylece o, Batı'nın Doğu üzerindeki söylemsel iktidarının altını oyar.

\section{4. İktidarın Çökertilmesi ve Modernliğin Reddi}

Foucault'nun devrime yaklaşımını belirleyen bir diğer şey ise soykütükçü çalışmanın temelini oluşturan iktidar boyutudur. İran'a varışını müteakip, hemen devrime ilişkin bir soruşturmaya girişen filozof, Beni Sadr'ın da ifade ettiği gibi "iktidar kavramının düşünmek", "bir halkı ayağa kaldıran bu devrimin nasıl meydana geldiğini anlamak" istiyordu". ${ }^{29}$ İktidarın üretimi ve uygulanması kadar askıya alınması da Foucault'nun ilgi alanı dahilindeydi. Foucaultçu bilgi/iktidar analizinin amacı iktidarın oluşum teknik ve stratejilerini, zaaflarını deşifre ederek direnişe katkı sağlamaktı. Bununla

26 Foucault, "Foucault'nun Atoussa H.'ye Yanıtı", Janet Afary ve Kevin B. Anderson, Foucault ve Iran Devrimi- Toplumsal Cinsiyet ve Íslamcılı̆̆ın Ayartmaları içinde, s. 268.

27 Mendieta, E., "Spiritual Politics and Post-secular Authenticity: Foucault and Habermas on post-metaphysical religion", in Gorski, P., Kim, D., Torpe, J. (eds) The Post-Secular in Question: Religion in Contemporary Society. New York: NYU Press, s. 2012, s. 319.

28 Foucault-oryantalizm ilişkisinin bu perspektiften bir değerlendirmesi için bkz. Almond, s. $12-22$.

29 Didier Eribon, Michel Foucault, (Çev. Şule Çiltaş), İstanbul: Ayrıntı Yayınları, 2012, s. 327. 
beraber iktidar ile sarmalanan direnişin bir kurtuluş vaadi olmadığını da hatırda tutmak gerekir.

Çalışmalarına aşina olanların bildiği gibi Foucault'nun nazarında modernleşme aynı zamanda iktidarın yoğunlaşmasını, iktidar söylem ve pratiklerinin tahkim ve takviyesini, tüm toplumsal gövdeye daha derinden ve daha ince teknik ve stratejilerle kök salmasını ifade etmektedir. Dolayısıyla onun için modern iktidar ile despotizm arasında yakın bir ilişkinin varlığını gözden kaçmaz. İran örneğinde iç içe geçen olgular olan modernlik ve modern iktidar temsilini şahın iktidarında bulmaktaydı. Batı dışında vuku bulan bu devrim tam da modernleşmenin temsilcisi olan bu despotik figürün mutlak reddi üzerinden kendini ifade etmekteydi. Modern despotik monarşiye karşı isyan eden kitleler aynı zamanda şahın cebri ve arkaik modernleşme projesine karşı ayaklanmışlardır. Soyguna dönüşen arkaik modernleşme projesine karşı oluşu ve Batı taklidine meydan okuması sebebiyle devrim aynı zamanda bir "öze dönüş" hareketiydi. ${ }^{30}$ Batıya meydan okuma girişimi olan devrim, Bat1 rasyonalitesine, modernleşme projesinin evrenselliğine meydan okuyan bir söylemler bütünlügüne saldırıyordu. Daha ilginç olan ise devrimin Aydınlanma'nın üstesinden geldiğini iddia ettiği “din” tarafından yönlendirilmesiydi. Şüphesiz tüm bu Batı dışı tema ve epizotlar Foucault gibi Batı rasyonalitesinin sınırlarını ve işleyişinin tümden farklı1ığını göstermek isteyen biri için bulunmaz malzeme ve bir deneyim alanını teşkil ediyordu.

Modenite eleştirisini tamamlayacak, modern iktidarı üretmeyecek Batı-dışı /Batılı olmayan bir söylem ve alternatif arayışında olan Foucault, İranlıların dini mobilizasyonunun şah diktatörlüğü tarafından kurulan modernist iktidar teknolojilerinin üstesinden gelinmesinin (overcome) otantik (authentic) yolu olduğunu düşünüyordu. ${ }^{31}$ Göstericilerin gösteriler boyunca sergiledikleri siyasal pratikler, etik öznellik(ler) yeni bir iktidar pratiğinin oluşumunu haber vermekteydiler. Yukarıda belirttiğimiz gibi Foucault, bir politik program vaaz eden ve salt iktidarın el değiştirmesine odaklanan bir devrim

30 Foucault, "Şah Yüzyıl Geç Kaldı”, s.290; Öze dönüş açıç̧a bir Şii İslami bir geleneğe dönüştü. Foucault'nun nazarında bu geleneğe dönüş modernliği ret etmenin yabacılaştırıcı ve salt politik olmayan otantik yoluydu. Bkz. Jelle Versieren and Brecht de Smet, "The Passive Revolution of Spiritual Politics: Gramsci and Foucault on Modernity, Transition and Religion" Ed. David Kreps, Gramsci and Foucault : a reassessment, Ashgate Publishing, 2015, s. 122; M. Leezenberg, s. 78.

31 Bernauer, J. "Foucault's Philosophy of Religion". In Michel Foucault and Theology, edited by J. Bernauer and J. Carrette. Aldershot: Ashgate, 2004, s. 90-92. 
anlayışına kesinlikle karşıdır; zira bu tür devrimler sadece oyun kartlarının el değiştirmesi mahiyetinde olduğundan gerçek bir toplumsal dönüşümü ve toplumsal kırılmayı ifade etmemekteydiler. Foucaultcu perspektifinden gerçek bir devrim/değişim toplumun her yanında işleyen gündelik iktidar ilişkilerinin değişimini ifade eder. İktidar aşağıdan yukarıya doğru işleyen merkezsiz bir ilişkiler ağı olduğundan salt iktidar piramidinin tepesinin ele geçirilmesine odaklanan, iktidarın mahiyetinde bir değişimi yaratmayan devrimler iktidarın geçirilmesinden ve yeniden üretilmesinden başka bir şey ifade etmezler.

Oysa Deleuze'ün de bir konuşmasında ifade ettiği gibi Foucault'nun amac1 iktidarı ele geçirmek değil, onu çökertmekti. Foucault'nun kendisini büyüleyen “iktidarın çöküşü” düşüncesinin tümden tecessüsünü İran' da gördügüne şüphe yok.O, 68 Baharı'ndaki olayları da iktidarı/gücü ele geçirmeyi hedeflemediği için olumlar. ${ }^{32} \mathrm{Bu}$ sebeple eğer İran Devrimi ile Batı'daki devrimler arasında bir benzerlik aranacak ya da karşılaştırma yapılacaksa bu belki bir nebze 68 Olayları olabilir. Zira söz konu devrimde eylemciler iktidarı ele geçirmeyi değil iktidarı çökertmeyi, "düzenin zayıflıklarını ortaya çıkartmaya yarayan" yeni eylem ve örgütlenme biçimleri geliştirmeyi denemişler ve isyanlarını bir sınıfsal çelişki üzerine inşa etmemiş, ${ }^{33}$ bir (lider, parti, sınıf vb.) öncüye tabi kılmamışlardır. ${ }^{34}$ Fakat yine de söz konusu eylemlerde İslam Devrimi'nin radikalliğinden eser yoktur. Çünkü tüm radikalliğine ve yeniliğine karşın 68 Olayları modernliğin içinden vücuda gelmekte ve Batılı bir felsefi arka plana dayanmaktadır. Bu sebeple 68 Olayları "tanıdık", dolayısıyla "makul" gelmekte ve Batılı entelektüel kanonu tarafından büyük bir coşkuyla sahiplenilirken, İran Devrimi "ya-

32 Foucault, "Michel Foucault ile Söyleşi: Mayıs “68 Boyunca "Sözcükler” ile "Şeyler" Arasında", Cogito, sayı, 14, 1998, s. 126-130. Ona göre Mayıs 68 Olayları mevcut topluma karşı çıkmanın çağdaş Marksist yönelimlerinin sınırları dışında da mümkün olabileceğinin göstermişti.

33 Foucault, "Michel Foucault ile Söyleşi: Mayıs “68 Boyunca "Sözcükler” ile "Şeyler" Arasında", Cogito, sayı, 14, 1998, s. 126-130. Ona göre Mayıs 68 Olayları mevcut topluma karşı çıkmanın çağdaş Marksist yönelimlerinin sınırları dışında da mümkün olabileceğinin göstermişti.

34 Foucault'nun ifadesiyle 68 Mayıs'1, devrimci düşünceyi “iktidara aşık olmuş” olan "siyasi asetikler, hırçın militanlar, teori teröristleri, siyasetin ve siyasi söylemin katışıksız düzenini korumak isteyenler. Devrim bürokratları ve hakikat memurları"nın "öncülük" arzusundan kurtarmıştır. Bkz. Foucault M., “Anti-Oedipus'a Önsöz”, Entelektüelin Siyasi Işslevi, (Çev. Ergüden I. O. Akınhay, F. Keskin), İstanbul: Ayrıntı Yayınları, 2000, s.55. 
bancılı̆̆g”, dolayısıyla 'anormalliği’ sebebiyle mahkûm edilmektedir. Foucault'nun belirttiği gibi devrimde sağ ve sol aydınları ürküten bir şey vardır. Onları ürküten ve devrimi yabancı kılan şey hiç şüphesiz devrimde dinin oynadığ 1 roldür.

\section{Siyasi Maneviyat ve Gösteri Olarak Devrim}

İran'da olup bitenlerin modern epistemenin ve politik rasyonalizmin kavramlarıyla anlaşılamayacağını düşünen Foucault'nun en önemli katkısı konuyu izah etmeye yarayacak yeni kavramlar, yeni avadanlıklar inşa etmesidir. Tanımlayıcı ilkesinin din, taşıyıcı liderinin bir "ermiş/aziz" olduğu bu devrimin kendisinin de bir tezahürü, varoluşa gelişi olduğunu düşündüğü şeyi Foucault "siyasi manevilik" olarak kavramsallaştırır. Bu kavram onun devrimde zuhura geldiğini düşündüğü şeyin, yeni politika yapma tarzının ifadesiydi. Modernliğin vaaz ettiğinden kökten bir değişiklik gösteren bu politik eylem tarzı, aynı zamanda bir öznellik inşa süreci ve etik tarzıydı. Dinsel ve dindışı, özel ve kamusal ayrımı yapmayan, politik yaşam ile gündelik yaşamı birbirinden ayırmayan yeni bir yaşam ve siyaset tarzıydı. Dini maneviyatın devrimdeki rolü sebebiyle devrim büyülü ve tutkulu bir eyleme dönüşmüştür. Ona göre İran'daki devrim (bir sınıf kavgası değil) "bir cemaat yaşantısı" ve "devamlı tekrarlanan bir çeşit ayin"di. Din, insanlar üzerinde "ürkütücü kuşatıcı etkisi”yle ve kendisini "mücadele ve fedakârlık dini kılan içeriği"yle devrimde asli bir role sahipti. Dinin devrimdeki bu rolü kesinlikle Marksistlerin sandığg gibi “çok büyük farklılıktaki çıkarlar arasındaki çelişkileri maskeleyen veya aralarında bir çeşit bir kutsal bir birlik şekillendiren ideolojinin rolü değil"di. ${ }^{35}$ İslam, isyan, öznellik ve bilinç üreten politik manevilikti. Bu maneviyat siyasal iktidara sınır çizip iktidarın mutlaklaşmasını engellediği gibi bireyin kendi benliğini inşa etmesini mümkün kılan bir dizi "benlik teknolojisi”nin de kaynağıydı.

Foucault'ya göre İranlıların hayatları pahasına aradıkları siyasi manevilik aslında Batı'nın da geçmişinde var olan, fakat Rönesans ve Hıristiyanlığın büyük buhranı ile birlikte unutulup ${ }^{36}$ giden bir yönetim tarzı ve yaşam pra-

\footnotetext{
Foucault, "İran: Ruhsuz Dünyanın Ruhu", s. 82-83.

36 Foucault, “İranlılar Ne Düşlüyor?”, s. 266. Carrette’ye göre Foucault'nun İran'daki siyasi maneviliğe olan ilgisi ile Hıristiyanlık ve "pastoral iktidar" üzerine çalışmaları arasında benzerlikler vardır. Onun Batının politik maneviliği unutmasından bahsetmesi bunun göstergesidir. Foucault, siyasi manevilik kavramını İran deneyiminden önce 1978 Mayısı'nda yapılan yönetim ve hakikat ilişkinin sorunsallaştırıldığı bir tartışmada
} 
tiğiydi. Onun için Foucault, konu bağlamında Batı tarihinden Anabaptistleri, Münzer ve Cromwell zamanındaki Presbyteriansları anımsar. ${ }^{37}$ Şahın iktidardan uzaklaştııılmasını Batı tarihindeki olaylar ile karşılaştıran filozof, İran'daki olayların erken modern dönemdeki devrimci dini hareketlerin terimleriyle anlaşılabileceğini düşünür. ${ }^{38}$ Açıkça Foucault, hem dini hem de politik bir hareket olarak çağdaş muhalif Şiilik ile Reformasyon sürecindeki Protestanlık arasında benzerlik görmüştür. Fakat Batı bu siyasi maneviyatı modern dönem ile birlikte kaybetmişti. ${ }^{39}$

Foucault için devrimi modern devrimlerin yasasına aykırı, sui generis k1lan en önemli şey hiç şüphesiz söz konusu siyasi manevilikti. Bu devrimi diğer devrimlerden ayıran ve onun radikal bir şekilde farklı kılan siyasi manevilik aynı zamanda devrimin olumsal karakterini oluşturmaktaydı. Ona göre bu, modern Batının yabancısı olduğu yeni bir siyaset yapma tarzı ve öznellik inşa etme biçimiydi. Burada katılımcılar kadar gözlemciler için devrimin ima ve işaret ettiği şey, farklı bir düşünüşün ve eyleyişin mümkün oluşunun somut ifade ve tezahürü olmasıydı. Sokakta yaşananlar yeni bir politik tahayyül ve öznelliğin zuhurunun alametiydi. Zaten Batı politik tahayyülün sınırlarına dayandığını düşünen Foucault'nun Japonya'da bir söyleşide ifade ettiği gibi yeni bir felsefe Avrupa dışında doğacaktı. ${ }^{40} \mathrm{Hem}$ bir politik karş1-iktidar formu olarak hem de kendini ve ötekini yönetmenin yeni bir formu olan siyasi manevilik Foucault için Batı liberal demokrasileri ile rekabet edebilecek ve ona alternatif olabilecek bir potansiyele sahipti.

Yaşamı boyunca Avrupa kültürünün kılı kırk yaran analizlerini yaparken

kullanmıştır. Ayrıca Şubat 1978'de Colege de France'da manevi yönetim ile reformasyon ilişkisi üzerinde durması İran Devrimi öncesi bu konuyla ilgilendiğini göstermektedir. Bkz. J.R. Carrette, Foucault and Religion. London: Routledge, 2000, s. 137.

37 Foucault, “Tahran: Şaha Karşı İman”, Janet Afary ve Kevin B. Anderson, Foucault ve Iran Devrimi- Toplumsal Cinsiyet ve İslamcılı̆̆ın Ayartmaları içinde, s. 255.

38 Corey McCall, "Foucault, Iran, and the Question of Religious Revolt," International Studies in Philosophy, 40.1 (2008), s. 3.

39 Foucault, "Tahran: Şaha Karşı İman”, s. 266; Ayrıca bkz. Mahmoud Khatami, "Foucault on The Islamic Revolution of Iran", Journal of Muslim Minority Affairs, Vol. 23, No. 1, 2003, s. 121-122.

$40 \quad 1978$ 'de Japonya' ya yaptığı biri ziyarette "Batı felsefesinin çağı”nın sonundan bahseder; ona göre eğer gelecekte bir felsefe olacaksa bu felsefe Avrupa'nın dışında doğmalı, Batılı ve Batılı olmayanların olmayanın eşit şartlarda karşılaşmasının sonucu olmalıdır. Bkz. Carrette, Jeremy R. Religion and Culture: Michel Foucault. New York: Routledge, 1999, s. 113. 
asla eleştiri silahını elde bırakmayan Foucault'nun geçmiş yazılarındaki eleştiri daima negatif bir karakter taşır. Zira Foucaultgil eleştiri bir kurtuluş (umut) vaat etmez. O, iktidar/bilgi neticesinde vücuda gelen söylemelere özsel bir gerçeklik (hakikat) atfetmediğinden söylemler arasında bir hiyerarşi de kurmaz. Bir söylem adına bir diğerinden kurtuluşu özgürlük olarak nitelemez. Fakat İranlı entelektüel Baqir Parham ile yaptığı röportajda İran'daki olup bitenlere ilgisini "spesifik entelektüel"in rolü gibi diğer entelektüel ve felsefi ilgi alanları üzerinden kavramsallaştıran Foucault'nun entelektüel yönelişine burada yeni bir boyut eklenir: Umut. Başka bir ifadeyle eleştirinin sadece negatif değil, pozitif olabilirliği. Buradaki umut yeni bir siyasal tahayyül inşa etmenin gerekliliği ve mümkün olabilirliği düşüncesidir.

Foucault, tıpkı Antik Yunan'ın varoluş etiğini modernliğin disipliner etiği karşısında kayırdığı gibi yeni siyasi maneviliği de modernlik karşısında kayırır. Aslında Foucault son dönem çalışmaları ile hiçbir çözüm ve alternatif önermediği eleştirilerine bir çeşit cevap olarak bireylerin kendilerini inşa etmesini ön plana çıkarır. Kişiye dişsal baskıcı/disipliner pratiklerden bireylerin kendilerini inşa ettikleri kendilik teknolojileri üzerine yoğunlaşır.

Buraya kadar anlatılanlardan da anlaşılacağı gibi devrimi asıl anlamlı kılan ve künhünü oluşturan şey onun sadece dışsal ve baskıcı bir iktidara yönelen radikal reddi değil, öncelikle bireylerin kendileri ve diğer öznelerle/ nesnelerle kurdukları ilişkileri diğer devrimlerden farklı olarak yinelemesi değil yenilemesidir. Başka bir ifadeyle Foucault'ya göre özneler baskıcı ve dışsal bir iktidarı alt etmekten çok kendi nefislerini (varlık tarzlarını) değiştirmeye ve diğer öznelerle yeni bir tarzda iktidar ilişkileri oluşturmaya yönelmişlerdir. Kendi ifadesiyle:

Ayaklanmada İranlılar kendilerine ayaklanmanın- belki de künhünü oluşturan şu sözü söylediler: "Kuşkusuz biz bu rejimi değiştirip, bu insanı başımızdan atmak zorundayız. Bu kokuşmuş yönetimi, bütün ülkeyi, siyasi teşkilatı, ekonomik sitemi, yabancı siyaseti değiştirmek zorundayız. Fakat her şeyden önce kendimizi değiştirmek zorundayız. Bizim varlık tarzımızı bizim başkalarıyla, nesnelerle ebediyetle Tanrı vs. ile olan ilişkimiz değişmeli ve şayet bu yaşantımızdaki kökten değişim gerçekleşirse ancak o zaman gerçek bir devrim olur.” Ben inanıyorum ki İslamın devrimde bir rol oynadığı yer burasıdır...O halde İslam'ın 1978 yılında, tamamen ruhsuz bir 
dünyanın ruhu olduğundan dolayı halkın afyonu olmadığını söyleyelim. ${ }^{41}$

Yani din uyutmamış isyan ettirmişti. İslam, onun deyimiyle bir "barut fiç1sı"ydı. ${ }^{42}$ Batı'da ayaklanmaları teşvik eden başka seküler ideolojiler zaten mevcuttu. İslamın farklı, asıl ve ayırıcı rolü özneleri isyan etmeye, siyasal iktidarı sınırlamaya ve değiştirmeye yöneltmekle beraber belki de bundan daha önemli olanı siyasal iktidar ile birlikte bireylerin kendi nefislerini değiştirmeye ve düzenlemeye sevk etmesi ve bunun mümkün kılacak benlik teknolojilerini, nefs pratiklerini temin etmesiydi. Başka bir ifadeyle bu devrimde bireyler (kendilerinden başlamak kaydiyla) hem kendilerini hem de dünyayı değiştirmeyi hedeflemekteydiler. Bu sebeple burada yeni bir varoluş etiği ve öznelliğin oluşumu iç içe geçmiştir. Devrimi farklı kılan onun içten dışa, bireyden topluma yönelmesi; aşağıdan yukarıya doğru oluşa gelmesidir. Bu sebeple solun sloganını ödünç alarak Foucault'nun İran Devrimi'ni farklı bir tarzda bir “topyekun devrim” teşebbüsü olarak gördüğünü söyleyebiliriz.

Foucault'nun devrimde tanık olduğu siyasal pratikler ve devrim soruşturması sırasında duyduğu şeyler aslında İslami etik ve siyasi ilkelerin pratize olmuş haliydi. Zira göstericiler yoğun bir şekilde eylemlerini dine refere etmekte fakat, sadece söylem ile yetinmeyerek arzuladıklarını(n oluşa gelmesi için) bizzat yaşamaktaydılar. Zaten devrimi radikal ve sahici kılan şey de bu yaşantı ve irade edileni kuvveden fiile çıkarma haliydi. Burada söz konusu olan siyasal ve toplumsal değişimin benliğin/kendiliğin değişiminden hareketle oluşa gelmesidir. Yani arzulanan değişim önce kişinin benliğinde/nefsinde tecelli etmelidir. Şayet bu gerçekleşirse siyasi iktidar ve iktidar ilişkilerinin onun takip etmesi kaçınılmazdı. Başka bir ifadeyle gündelik yaşamdaki mikro iktidar pratiklerinin ve etik varoluş tarzındaki değişimin makro siyasi iktidarı değiştirmesi kaçınılmazdır. Söz konusu bu düşüncelerin bir kısım İslami etik ve politik (ki içi içedir) ilkelerin Foucault'nun dile tercümesi olduğunu söyleyebiliriz. Foucault, tanığı olduğu bir pratiği teorize etmiştir.

Söz konusu İslami etik ilkelere göre kişi(ler) kendi nefsinde/beninde/aslında olanı değiştirmedikçe başka bir ifadeyle asli olan değişimi gerçekleştir-

${ }^{41}$ Foucault, "İran: Ruhsuz Dünyanın Ruhu”, s. 85-86.

42 Foucault, "İslam Denen Barut Fıçısı”, s. 302. 
medikçe siyasal ve toplumsal bir (dışsal) değişim yaşanmayacaktır. ${ }^{43}$ Kişinin kendisini değiştirmesini (benliğin/nefsin dönüşümünü) büyük ve asli (içsel) bir zafer olarak niteleyip onu (büyük cihad) dışsal bir zafere (küçük cihad) yeğleyen İslami ilke, İslami öznelliğin oluşumunun arkasındaki ilkedir. İslami öznellik siyasal iktidarın değişimini benliğin değişime rapteder ve ona nispetle arızi sayar. Bu değişim formu, siyasal iktidarın değişiminin ya da alt edilmesinin kişinin nefsinde olanı değiştirmesini yani asli olanı gerçekleştirmesini takip edeceğini vaaz etmektedir. Din bunu gerçekleştirecek, benini şekillendirecek nefs pratikleri sunmaktadır.

Onun devrime ilişkin yazılarında devrime karakterini ve kimliğini kazandıran İslam, devrimin kazai ve arızı bir unsuru ya da salt bir boyutu değil, devrimin asli kaynağıdır. Bu rolü ideoloji ile karıştırmamak gerekir. İslam İran'da tüm bir toplumun kendisi aracılığıyla öznellik inşa ettiği bir öznellik modu, otorite ve kimlikti. Dini kişinin kendisiyle, dünya ve devlet ile ilişkilerinde radikal bir dönüşüm yaratığının farkında olan Foucault, İslam'ın insanın/toplumun yaşamını şekillendirme, değiştirme ve dönüştürme, öznellik üretme ve kitleleri mobilize etme gücüne derinden ilgi duymuştur. Devimde aşkın bir ilke yaşama yön vermiş, bireysel, toplumsal ve siyasi bir kontrol stratejine dönüşmüştür.

Foucault'nun vurguladığı gibi İran'daki yeni öznelliğin kaynağı açıkça İslamdı. Monarşiyi yıkma hedefine kitlenmiş kitlelerin ölüme hazır oluşu, Şii şahadet kültü, devrimci belağat, kefaret kültleri ve bunların modern bir iktidarı yıkma amacına yönelmesi Foucault'yu derinden etkilemiştir. O, İslamı bir çeşit direniş dini olarak okur: “....İran İslamdan halkına devlet iktidarına direnmesi için tanımı yapılmamış kaynaklar bahşeden bir inanç üretti”. ${ }^{44}$ "Önce inançlı kişileri çarpışmaya çağıran, sonra da çarpışmada düşenleri anan bu din... zaferden çok şehitliğe odaklanmıştı." ${ }^{45}$ İşte devrimci hareket "ahiretten çok bu dünyanın değiştirilmesinden bahseden bir din"in "soluğunu üflemekte"ydi. ${ }^{46}$

Şii İslam hakkındaki düşüncesi pek de eleştirel olmayan Foucault'nun Şiilik algısı Şiilerin ben idrakini yansıtan özsel bir karakter taşır. Ona göre Şiilik "bügün ve geçmişte defalarca sade halkı harekete geçiren "hoşnutsuz-

43 Kur'an-1 Kerim; Rad 13.

44 Foucault, "Tahran: Şaha Karşı İman”, s. 259; Eribon, s. 307.

45 Foucault, "Tahran: Şaha Karşı İman”, s. 255.

46 Foucault, "İran Ayaklanmasının Efsanevi Önderi”, s. 283. 
luk, öfke, sefalet, çaresizlik biçimlerinin binlercesini bir güce dönüştüren" bir mücadele ve ifade biçimidir. ${ }^{47}$ Foucault'nun maneviyat olarak (Şii) İslam okuması büyük ölçüde Henry Gorbin ve Louis Masignon kaynaklıdır. ${ }^{48}$ Siyasi bir tür direniş olarak İslam, Şeriati ve Humeyni tarafından popüler kılınmıştı. Açıkça devrim sürecinde hem Foucault'nun "görünmez mevcut" olarak vasfettiği Ali Şeriati hem de devrimin "mistik lider"i Humeyni ve tüm diğer İslamcılar şaha ve Batıya karşı Şii tarih ve geleneğini mobilize etmişlerdi. Muhalefetin organizasyonunda Şiiliğin Muharrem ve Kerbela ritüelleri etkin rol oynamıştır. ${ }^{49}$ Foucault'nun ifadesiyle "İran' da siyasi takvimi dini takvim belirliyor"du. ${ }^{50}$ Kaset vb. modern araçlarla yaygınlaştırılsa da mücadele geleneksel bir retoriğin içinden ifade edildi; örneğin Şah "Yezit", Humeyni "Hüseyin"di.

Hiç şüphesiz devrimin mesihçi karakterinin kendisinin somutlaştı̆̆ en önemli kişi Humeyni'ydi. Sokağa dökülen ve yaşamlarını bile pazarlık konusu yapmaktan vazgeçen kitlelerin tartışmasız bağlılık duydukları bir figür olan Humeyni, isyanın birleştirici sembolüydü. Foucault için devrimin kendisi gibi devrimin lideri Humeyni de devrim ve devrimci öznelerin motivasyonu gibi çarpıcı bir figürdü. Foucault, "devrimin mistik lideri” olarak adlandırdığı Humeyni’yi "kral” karşısında bir "aziz olarak konumlandırır: “İran'daki durum, kralın ve ermişin, silahlı egemenin ve sefil sürgünün geleneksel sancakları altında düzenlenen bir atlı mızrak dövüşü gibi anlaşılabilir; despotun karşılaştığı adam çıplak elleriyle dövüş meydanına çıkıyor ve halk onu bağrına basıyor. Bu imgenin kendi gücü olduğu gibi, milyonlarca ölünün imzasını attığı bir gerçeklikten de bahsediyor." ${ }^{51} \mathrm{Bu}$ sebeple devrim, modern ile modernliğin alt ettiğini düşündüğü farklı bir dünyanın karşılaşmasıdır.

Ona göre şahın tahtını sallayan bir isyanın siyasi/siyasetçi olmayan lideri ve

\footnotetext{
47 Foucault, "İranlılar Ne Düşlüyor?”, s. 258-259.

48 Carrette, 2000, s.139; Georg Stauth, "Revolutions In Spiritless Times. An Essay On Michel Foucault's Enquiries Into The Iranian Revolution.” International Sociology, 6 (3), 1991, s. Stauth 1991: 268; Ghamari-Tabrizi 2012, s. 282; Leezenberg, 1999:65.

49 Şiiliğin Muharrem ve Kerbela ritüellerinin İslamcılar tarafında muhalefetin organizasyonunda kullanımı için bkz. Janet Afary ve Kevin B. Anderson, s. 84-95.

50 Foucault, "İran'da İsyan Teyp Kasetleriyle Yay1lıyor", Janet Afary ve Kevin B. Anderson, Foucault ve Iran Devrimi- Toplumsal Cinsiyet ve Íslamcilı̆̆ın Ayartmaları içinde, s. 274.

${ }^{51}$ Foucault, “İranlılar Ne Düşlüyor?”, s. 260.
} 
"efsanevi bir şahsiyet" olan Humeyni, "ülkesinin tüm basın yayın organları tarafından desteklense dahi" hiçbir siyasi liderin sahip olmadığı olamayacağ "kişisel ve yoğun bir bağlıllı̆ın nesnesi”dir. Bu ise, "muhtemelen üç şeyin sonucudur. Humeyni orada değil. Son on beş yıldır sürgünde yaşıyor ve Şah ayrılmadan dönmek istemiyor. Humeyni hiçbir şey demiyor, Şaha, rejime, bağımlılığa hayır demekten başka hiçbir şey söylemiyor. Son olarak Humeyni, siyasetçi değil. Humeyni partisi diye bir şey olmayacak; Humeyni hükümeti olmayacak. Humeyni, toplu bir istencin odak noktasıdır". ${ }^{52}$ Ancak halk ile arasında "gizemli akım" olan ${ }^{53}$ Humeyni, 1978 şubatında tarihin bir ironisi olarak laisizmin başkentinden muzaffer bir lider olarak ülkesine döndüğü zaman herkes bu "yaşlı adam"1n ülkesi için gerçekten neyi planladığını anlayacaktı: İslam Cumhuriyeti. Humeyni’nin İslamcı hükümeti Foucault'nun İran'ın sokaklarında duyduğu İslami hükümet değildi. $\mathrm{Bu}$ tam anlamıla dünyevi ve reel bir iktidard. Yeni yönetimde dünyevi iktidarı halk adına gözetlemeye, doğrudan icra etmeye başlayan mollalar dünyevi iktidarı kontrol etmekte en az sekülerler kadar mahir olduklarını gösterdiler. Devrim, kısa süre sonra tüm devrimlerin yasasına uyarak muhaliflerin ve muarızların tasfiyesine girişti. Ruhaniler, devrimcilerin arzuladıkları "İslami hükümet”"ten dünyevi bir iktidar devşirmişti. Foucault nedamet değil, fakat hayal kırıklığı yaşamıştı.

Peki o, İslami hükümetten ne anlamıştı? Foucault, devrimin idealinin "İslami hükümet” olduğunun farkındaydı. Zira İran sokaklarında rastladığ 1 her kesimden kişiler "ne istiyorsunuz?" sorusuna "İslami hükümet" cevabını vermişlerdi. Ne İran sokaklarında rastladığı kişilerin ne de ruhanilerin İslami hükümet ile kast ettikleri şeyin bir siyasal iktidar ve onun üzerinde hakimiyet kurmak olmadığından emin olmuş görünen Foucault, okuyucusunu da buna ikna etmek ister. Hiyerarşiden kaçınacak ve özgürlükleri koruyacak olan bu hükümet, politik yaşama "manevi bir boyut" getirecekti. ${ }^{54}$ Ruhanilerin siyasal iktidarı arzulamadıkları konusunda yanılan ve devrimin farklı bir şekilde yol almaya başladığını gören Foucault, erken bir tarihte yeni yönetimin icraatlarını eleştirse de muarızlarının eleştiri oklarının sürekli olarak kendisini takip etmesinden kurtulamayacaktı.

\footnotetext{
Foucault, "İran Ayaklanmasının Efsanevî Önderi”, s. 282.

Foucault, "İranlılar Ne Düşlüyor?", s. 261.

Foucault, “İranlılar Ne Düşlüyor?”, s. 264-265.
} 


\section{Ayaklanmak Faydasız mı?: Tikelliklere Saygı Duymak ve Eleştirilere Göğüs Germek}

Foucault'yu ruhanilerin iktidar arzusunu görmemekle ve naif olmakla suçlayan eleştirmenlerin onun isyancıların İslami hükümet ile arzuladıklarını düşündüğü şeyi, yeni yönetimin pratiğine indirgemeleri de son derece yanlıştır. Zira isyanın taşıdığı ve imlediği arzu potansiyeli bir devrimci hükümetin reel politiğine indirgenemez. Gerçekte herhangi bir İslami toplumda olduğu gibi İran'da da “İslami hükümet” göstericilerin (halkın murakabesine tabii olacak olan) şeriat yani bir "hukuk düzeni"ne olan özlemlerini ifade etmekteydi, yoksa ruhanilerin iktidarını değil... Doğrusu Foucault, gösterilerde şahit olduğu siyasi maneviyatın bir kadro tarafından nasıl manipüle edileceğini tahmin edememişti. Fakat bu onun asıl anlamak istediği şeyin sadece bir epizodundan ibaretti.

Hiç şüphesiz Foucault, İran'da olup biten olayın tarihsel biricikliğini, özgüllüğünü, ağırlığını kavrayan ve dillendiren birkaç kişiden biri ve belki de en önemlisidir. İran'da “tüm gücüyle başkaldıran dinsel patlamanın bir kez zafer kazanıldıktan sonra yok olup gitmeyeceğini hemen gören" ${ }^{55}$ ve erken bir dönemde İslamın devasa politik gücünün, dönüştürücü enerjisinin farkına varan Foucault, devrimle birlikte doğmakta olan yeni politika yapma biçiminin yani siyasi maneviyatın tüm Ortadoğu ülkelerini etkileyeceğini, monarşilerin, kralların tahtını sarsacağını ifade eder:

Belki bunun tarihsel önemi, bilinen “devrim” kalıbına uymasında değil, Ortadoğu' daki mevcut siyasi durumu, dolayısıyla küresel stratejik dengeyi altüst etme potansiyelinde bulunacak. Şimdiye kadar bu harekete güç vermiş olan münferitliği, eğer genişleme gücü bulursa bundan sonra tehdit edici hale gelecektir. Dolayısıyla, "İslamcı" bir hareket olarak bütün bölgeyi ateşe verebilir, istikrarsız yönetimleri devirebilir, en sağlam yapının rahatını bozabilir. İslam sadece din değil, aynı zamanda yaşam biçimi, tarihe ve belirli bir uygarlığa bağlılıktır; bu din, yüz milyonlarca insan için devasa bir barut fiçısına kolaylıkla dönüşebilir. Dünden itibaren, her Müslüman devlet zamanın sınamış olduğu geleneklerini temel alan, içeriden yükselen bir devrim geçirebilir. ${ }^{56}$

Gerçekte Fransız Devrimi’nden beri dindışı-laik politikalar izleyen Batı si-

Eribon, Foucault, s. 312.

56 Foucault, "İslam Denen Barut Fıçısı”, s. 304. 
yasal düşüncesi için de yeni bir şey olan devrim, tamamen farklı bir karakterde olmakla beraber bekli de Fransız Devrimi sonrası ilk devrimdi. Fransız Devrimi, maneviliği politik alanın/olanın dışına sürerken, İran Devrimi onun politikaya/tarihe dahil etmişti. İslamın rehberlik ettiği devrim, "küresel sisteme karşı ilk büyük isyan", "en modern ve en çılgın ayaklanma biçimi"ydi. ${ }^{57}$

Devrimcilerin uygulamalarından hayal kırıklığına uğrayan Foucault, erken bir tarihte yeni yönetimin uygulamalarını eleştirmekten de geri kalmaz. Bazergan'a yazdığ açık mektupta devrimin tahmin etmediği bir yönde geliştiğini açıkça ifade/itiraf eder; İslami hükümetten umulan şey bir "mollalar hükümeti" değildi. ${ }^{58}$ Filozof burada devrim sonrası yapılanların devrim sürecinde kendisine söylenilenlerle ve şahit olduklarıyla uyuşmadığını dile getirir. Sözünü sakınmayan bir filozof olan Foucault, Haziran 1982'de kaleme aldığ “ “Ayaklanmak Faydasız mı?” başlıklı yazısında muarızlarına cevap vererek, devrimde olumladığı/selamladığı şeyin ne olduğunu ortaya koymaya çalışır. Fakat muarızlarının sürekli günah çıkarması ve itiraf etmesi baskına da boyun eğmez; nedamet getirmez. Mayıs ayında İslam cumhuriyetinin ilanını sonrası kaleme alınan yazısında görüşlerini yeni yaşanan gelişmeler doğrultusunda yeniden revize etmeye yanaşmayan Foucault, İran'da şahit olduğu olayların “aslı"nı yaşanan gelişmelere, reel politiğe indirgemeyi ret eder. Kendisine yöneltilen eleştirilere karşı çıkan filozof, dünkü Savak işkencelerini olduğu gibi bugünkü yönetimin el kesmesi vb. uygulamalarını da açıklıkla eleştirir ve burada bir görüş değişikliği olmadığını söyler. ${ }^{59}$ Fakat kitleleri sokağa döken, isyanı motive eden dinamiği/ siyasi maneviyatı devrimcilerin icraatlarına indirgemekten de özenle kaçınır. Ona göre;

“İran'daki hareket, kör coşkunun altında gizlenmiş olarak bulunan zorbalığ 1 ortaya çıkardığı sanılan devrimlerin 'yasasına' boyun eğmedi. Ayaklanmanın en iç ve en yoğun yaşanmış bölümünü oluşturan kısım, aşırı yüklü bir siyasi tartışma alanıyla doğrudan ilgilidir. Ama bu ilişki özdeşlik ilişkisi değildir. Ölecek olanların başvuracakları maneviyatın, köktenci bir ruhban sınıfının kanlı yöntemiyle hiçbir ortak noktası yoktur. İranlı din adamları, ayaklanmanın sahip olduğu anlamlarla rejimlerini resmileştirmek istemek-

Foucault, "İran Ayaklanmasının Efsanevi Önderi”, s. 282-283.

Foucault, "Başbakan Mehdi Bezirgân'a Açık Mektup”, 327-330.

Foucault, “Ayaklanmak Faydasız mı?”, s. 300. 
tedirler..." $" 60$

Foucault için asıl ve önemli olan kendisinin de ifade ettiği gibi devrimin geleceğini öngörmek değil, böyle bir harekettin içinde "yok edilemez olanı", "geçmişte olduğu gibi bugünde despotizmler için "tehditkâr olanı" bulup ortaya çıkarmaktı. Söz konusu yazıda filozof devrimin hatalarını kabul etmekle birlikte devrimin temel ilkesini yeniden onaylar. Ona göre eğer iktidarlar "mutlak olarak mutlak" değillerse bu bütün kabullerin ve zorlayıcı önlemlerin ardında tehdit ve şiddet ve ikna yöntemlerinin ötesinde hayatın artık kendini pazarlık malzemesi olarak öne sürmediği iktidarların bir şey yapamayıp insanların dar ağaçları ve makineli tüfekler karşısında ayaklandıkları o anın olabilirliği sayesindedir. ${ }^{61}$ Zira bir birey ve toplumun "artık itaat etmiyorum" dediği ve adaletsiz olarak değerlendirdiği bir iktidara karşı kendi bedenini ortaya koyduğu hareket ortadan kaldırılamaz. ${ }^{62}$ Hiçbir iktidar bunu imkânsız kılacak yetenekte değildir. Çünkü "bir iktidar karşısında hayatını tehlikeye atan insana efendilik taslanmaz." ${ }^{63}$ İşte bu sebeple tüm insanlığın kurtuluşunu temin etmeyecek de olsa ${ }^{64}$ ayaklanmak yararsız değildir. Devrimin bir politik programa dönüşmesi ayaklanmayı, o anı, o momenti anlamsız ve işlevsiz kılmaz; tarihe giriş yapan tikelliği yok et(e)mez.

Ayaklamanın haklı mı, haksız mı olduğu sorusu da onun için anlamsızdır. Sonuçta insanlar ayaklanıyor bu bir olgudur. Onun amacı ayaklamanın derin nedenlerini değil, hareketin yaşanış tarzını araştırmak ve anlamaktır. Ayaklanmanın kendisi bir muammadır. ${ }^{65} \mathrm{Bu}$ durumda ne ayaklanmanın nedenleri tümüyle ortaya konabilir ne de sonuçları tümden öngörülebilir. $\mathrm{O}$ tekil değil, daima çoğul bir potansiyele sahiptir. Bu sebeple ayaklanma reel politik tarafında kolonize edilemez. Yapılması gereken devrimin/şimdinin nasıl yaşandığını ortaya koymaktır. Yukarıda anlattığımız gibi onun için devrim bir çeşit içsel dönüşüm, cemaat yaşantısı, dinsel gösteri/ayin kısaca siyasi maneviyatt1.

60 Foucault, “Ayaklanmak Faydasız mı?”, s. 300.

${ }_{61}$ Foucault, “Ayaklanmak Faydasız mı?”, s. 298.

62 Foucault, “Ayaklanmak Faydasız mı?”, s. 297.

63 Foucault, “Ayaklanmak Faydasız mı?”, s. 300.

64 Ve sıradan insanların öznelliği tarihe bu şekilde dahil olur ve güç verir. O halka vaat edilmiş yarınları da halk garanti etmez. Bkz. Michel Foucault, "Ayaklanmak Faydasız mı?", s. 301.

65 Foucault, “Ayaklanmak Faydasız mı?”, s. 299. 
Devrimi farklı kılan ve ilgi odağına yerleştiren şey açıkça onun tikelliğidir. O, devrimde aynı olanı değil, farklı ve münferit olanı başka bir ifadeyle devrimlerin yasasına uymayanı bulup çıkarmak ister. Burada amaç bir genel ilke veya teori vaaz etmek ya da bir çıkarın müdafiliği yapmak değildir. Esas olan bugün vuku bulan tikelliğin ne olduğu ve olayın ne ifade ettiğidir. Bu nokta aynı zamanda isyan/devrim ile reel politik arasındaki boşluğu ve gerilimi oluşturur. Şöyle der Foucault:

"Stratejist, 'bu ölüm, bu feryat ya da bu ayaklanma, içinde bulunduğumuz özel durumda, bütünün ihtiyaçları ile şu veya bu genel ilke bakımından nasıl bir önem taşır?' diye soran kişidir. Bu stratejist ister siyasetçi, tarihçi ya da devrimci, isterse de şah veya ayetullah yanlısı olsun, benim teorik etik anlayışım her halükarda buna karşıdır. Benim etiğim 'strateji karşıııdır'. Bir tekillik doğduğunda saygı duymalı, devlet evrenselleri ihlâl ettiğinde taviz vermemeliyiz. Basit bir seçim bu ama zor bir iş: Biraz altına bakıp tarihi neyin paramparça ve altüst ettiğini izlemeli, biraz gerisinde durup siyaseti neyin kayıtsız şartsız sınırladığına dikkat etmeliyiz" ${ }^{96}$

Tarihi paramparça eden şeyin görmezden gelinmesi ve Foucault'nun devrime desteğinin "kanlı ve gerici" bir yönetime desteğe indirgenmesi onun devrime yaklaşımının değerini 1skalar. Zira yukarıda da ifade ettiğimiz gibi devrimin tekilliği reel politiği aşmaktadır. Bu sebeple devrimin potansiyelinin reel politik tarafından kolonize edilmesi mümkün değildir. Devrimin aslını oluşturan şey devrimin reel politik tarafından kuşatılmasına ve temellük edilmesine direnen şeydir. Gerçekte Foucault için devrim bir olay olarak bir yönüyle dünya tarihine ve reel siyasete aittir; ancak "oluş" yönüyle reel politiği aşar. Ona göre siyaset çıkarları belli olan öznelerin "çıkarlarının uzlaşı ve strateji zeminine indirgendiği bir oyun"dan yani (reel politikten) ibaret değildir. Bu sebeple başkaldırı, isyan, ayaklanma gibi “olay”ların ancak ve ancak çıkarların uzlaşısına indirgediği ölçüde anlaşılır kılınacağını iddia eden reel-politik oluşu kavrayamaz. Bu yüzden kendisine uymayanı "dinci, gerici, terörist" olarak damgalar. Zira devrim ile ortaya çıkan oluşlar mevcut düzenden başka bir düzen ve dünya olduğunu ima eder. Bu sebeple tekillikler mevcut düzende onarılamaz ve kapatılamaz kara delikler açar. Mevcut/fili olanı aşan isyanlardaki, devrimlerdeki tekil olay halini reel-po-

${ }^{66}$ Foucault'tan aktaran Bülent Diken, İsyan, Devrim, Eleştiri: Toplum Paradoksu, (Çev. Can Evren), İstanbul: Metis Yayınları, 2013, s. 20. 
litiğin gözlerinden bakarsak anlayamayız. ${ }^{67}$

Foucault, “Ayaklanma Faydasız mı?” yazısından sonra doğrudan İran Devrimi'ne bir daha dönmemişse de aslında Kant'ın "Devrim nedir?" metni üzerinden devrim üzerine düşünmeye devam etmiştir. Bu metin üzerindeki yorumları onun devrim(ler)e yaklaşımına dair önemli içerimlere sahiptir. Öncelikle Foucault'ya göre "Aydınlanma nedir?" sorusu ile birlikte "devrim nedir?” soruları Kant'ın kendi güncelliği ile karşı karşıya gelmesinin iki yüzüdür. ${ }^{68}$ Daha önce belirttiğimiz gibi Foucault'nun da devrim soruşturmasındaki amacı geçmişin tarihi yazmak ve geleceği öngörmek değil, bugün “olup bitmekte olan şeyin farkına varmak”tır. Dolayısıyla her iki filozofun da devrime yöneliş amacı devrim aracılığıyla bugünü anlama çabasıdır.

Foucault'ya göre Kant, devrimi bir ilerlemenin (insanlığın tarih boyunca ilerlediğinin (hatırlatıc1-geçmiş), bugün sürekli ilerlemeye devam etiğinin (kanıtlayıc1-bugün) ve yarında ilerlemeye devam edeceğinin (gösterici-yarın) kanıtı olmak anlamında) işareti olarak görür. İlerlemenin işaretini oluşturan şey ise Kant' 1 kendi ifadesiyle devrimin etrafında "çoşku derecesine varan özlem birliğinin" olmasıdır. Devrimde önemli olan devrimin kendisi değil, devrimi yapmayanların, devrimin aktörü olmayanların kafasından geçenlerdir. Başka bir ifadeyle devrimin faili olmayanların devrim ile kurdukları ilişkidir. Devrimden coşku duymak insanlıktaki ahlaki eğilimin bir işaretidir. Bir davranış biçim olarak değil, devrimde yer alanların benimsedikleri yıkıcı nitelikte bir ilke olarak değil, fakat seyredilecek bir gösteri olarak onu gözlemleyenlerin coşkularının odağ 1 olarak devrim ${ }^{69}$ bir signum rememorativum (hatırlatıcı işaret)dur; çünkü baştan/geçmişten beri var olan eğilimi gün yüzüne çıarır. Signum demonstrativum'dur; çünkü aynı eğilimin bugünkü geçerliliğini kanıtlar. Signum prognosticum'dur; çünkü devrimin sorgulanabilecek sonuçları varsa, devrim yoluyla açığa çıkmış olan eğilimi görmezlikten gelmek mümkün değildir. ${ }^{70}$ Dolayısıyla asıl olan devrimin başarısı, yani bir iktidarın alaşağı edilmesi değil, işaret ettiği, gösterdiği şeydir.

${ }_{67}$ Bülent Diken, Ísyan, Devrim, Eleştiri: Toplum Paradoksu, S.19-21.

68 Foucault, "Aydınlanma nedir?" Özne ve İktidar içinde (Çev. Işılk Ergüden, Osman Akınhay, Ferda Keskin), İstanbul: Ayrıntı Yayınları, s. 171.

69 Foucault, “Aydınlanma nedir?” s. 169.

70 Foucault, “Aydınlanma nedir?” s. 170. 
Hem tarihte bir olay, bir kopuş, bir alt üst oluş ve bir başarısızlık olarak hem de bir değerlendirme olarak devrim, tarihte insanlığın ilerlemesinde etkili olan bir eğilimin işaretidir. Burada felsefenin sorunu devrimin hangi parçalarının korunması veya bir model olarak değerlendirilmesi gerektiğini saptamak değil, devrimci girişimin kendisinden bambaşka bir şey olan bu devrim istemiyle, bu "devrim coşkusu"yla ne yapılabileceğini bilmektir. ${ }^{71}$ Yoksa "devrim daima her şeyin eski durumuna dönmesi riskiyle yüz yüze gelecektir, ama içeriği önemsiz bir olay olarak devrimin varlığı akıldan asla çıkarılamayacak bir potansiyel güce işaret etmektedir: "Gelecekteki tarih açısından, devrim ilerlemenin sürekliğinin güvencesidir."72

Foucault'nun Kant'ın devrime yaklaşımını analiz etmek için kullandığı "gösteri, "gözlemleyen(ler)", "devrim çoşkusu”, bu coşku/irade ile yapılabilinecek olan şey, "her şeyin eski durumuna dönmesi”, "etik", "potansiyel güç", "işaret” vb. vokabülerin onun İran Devrimi'ne dair yaptığı yorumların anlaşılması için münbit implikasyonlar içerdiği açıktır. İnsan, Foucault'un Kant'ın metni üzerine yaptığı bu yorumlarını okurken onun kendi devrim deneyiminden hareketle analiz yaptığını düşünmekten kendini alamaz. Hiç şüphesiz Foucault, Kant gibi devrimi sadece teorik olarak tefekkür etmemiş, bizatihi deneyimlemiş ve gözlemlemiştir. Bir yönetimin şiddet yoluyla yıkılmasını etik bulmayan ve onaylamayan Kant'tan farklı olarak Foucault, devrimci deneyimden ve eylemden derin bir heyecan duymuştur. Fakat Kant'a olduğu gibi onun için de esas olan devrimden çok devrimin işareti olduğu şey ve devrimci coşkuyla yapılacak olan şeydi. Kant'tan çok farklı bir şekilde devrim onun için tarihsel sürekliliğin ve ilerlemenin değil, yukarıda da bahsettiğimiz gibi yeni bir politik ve etik tahayyülün varoluşa gelişinin işaretiydi. $\mathrm{O}$, devrimden coşku duymuştu, bu yeni bir varoluş ettiğinin ve öznelliğinin inşasının, iktidarın askıya alınışının, başka bir düşünüşün ve politik tahayyülün mümkün oluşuna şahit olmanın coşkusuydu.

\section{Sonuç}

Foucault, devrim sirasında tüm bir ulusun bir inancın rehberliğinde ayaklanarak müşterek irade beyan etmesinden, monarşiye ve onun ordusuna meydan okumasından derinden etkilenmiş; tarafların karşılaşmasındaki devasa asimetrik şiddet potansiyeline karşın kitlelerin silahlara başvurmadan ya-

71 Foucault, “Aydınlanma nedir?” s. 172.

72 Foucault, “Aydınlanma nedir?” s. 171. 
şamları pahasına cesur ve kararlı bir şekilde "çıplak elleriyle” ölüme meydan okumasından, iktidara karşı direnmesinden heyecan duymuştur.

Foucault ve eleştirmelerinin de haklı olarak ifade ettikleri gibi bütün bir halkın isyanı ile açığa çıkan siyasal manevilik tüm yaşamı kuşatan yeni bir siyaset yapma tarzıydı. Foucault'ya göre bu siyaset yapma ve eyleme tarz1 modern Batı'nın yabancısı olduğu (ya da çoktandır unuttuğu) yeni bir politik tahayyül ve eylem tarzıydı. Bir arkeolog olarak süreklilik yanılsamalarına karşın Batı bilgi sistemlerini sabırla kazıyarak derinlerindeki kesintileri gün yüzüne çıkaran, modern epistemenin yok olmakta olduğunu ifşa eden, bir soykütükçü olarak tarihçilerin attıkları dügümleri çözen, hakikat/bilgi iddialarının gerisindeki iktidar arzusunu açığa çıkaran, modernliği bizi kuşatan bir panoptikon olarak düşünen Foucault'nun Batı'nın dışında doğuşunu gördüğü alternatif modernliğin dışın1/ötekisini gösteren dolayısyla Batı aklı için düşünülemeyecek olan bir şeydi. Zira İslam (tıpkı düşüncemizin sınırlarını gösteren Borges'in hikâyesinde olduğu gibi) şeylerin farklı bir düzeni ve eşyanın farklı bir tasnifini vaaz etmekteydi. Batı toplumlarının da bu siyasi maneviyattan öğrenecekleri vardı. İlkelerini Batılı düşüncenin dişında faklı bir kaynaktan (dini düşünceden) alan yeni bir tür siyasal hareket olan siyasi maneviyat disipliner pratiklerle iç içe geçen Batılı sağ ve sol modern siyasetlere alternatif oluşturabilirdi. Devrim, Batı dışı bir düşünce biçiminin en azından imkân dahilinde olduğunu göstermektedir. Burada Foucault'nun düşüncesine önceki çalışmalarında pek görülmeyen bir iyimserliğin dahil olduğu açıktır.

Devrim ile birlikte ortaya çıkan yeni bir siyasi tahayyül biçimi olan siyasi manevilik, modern siyasi rasyonalizmden tamamen farklı karakterde, bireysel olanı toplumsal olandan ayırmayan bir politika yapma tarzıydı. Foucault'nun devrim soruşturması sırasında tanık olduğu ve duyduğu şeyler; siyasal olan ile dini olanın bütünlük arz etmesi, öznelerin benliklerine şekil vermeyi siyasi değişime öncelemesi, buradan hareketle tüm gündelik yaşamı ve siyasal iktidarı biçimlendirmesi ve kontrol etmesi tüm yaşamı ihata etmeyi ve şekillendirmeyi amaçlayan dini bir maneviyatın sonucuydu. $\mathrm{Bu}$ değişim formunda maneviyat, etik ve siyaset iç içe geçerek bir bütünlük oluşturur. Bu maneviyat özneyi olduğu kadar düzeni de kontrol etme özelliğine sahiptir. Başka bir ifadeyle aşkın bir ilke olan din hem bireysel hem de siyasal yaşama rehberlik etmekteydi ki bu seküler politik rasyonalizmin aşina olmadığ bir şeydi. 
Devrim, dinin basit bir şekilde bir uzlaşı ve aracı değil, bir direniş (karş1 çıkma, yıkma) aynı zamanda inşa aracı olduğunu göstermiştir. Din uyutmamış ayaklandırmıştır. Devrim reel pratiği onaylamamış "oluş"u esas almıştır. Hiç şüphesiz devrimin göze çarpan ayırıcı vasıflarından birisi de onun mevcut siyasal toplum ve devrim modellerine uymamasıdır. Müşterek iradenin eylemi olan devrim sınıfsal bir karakter arz etmemekte, ne bir çatışma dinamiğine ve de bir uzlaşı arzusuna dayanmamaktadır. Bu da devrimi sağ ve sol devrim ve siyaset tarzından ayırmakta, iktidara karşı çıkmanın Batı dışı başka mümkün yollarını varlığını göstermektedir.

Maneviliği yeniden etkin kılmak arzusuyla devrim, liner zamanın ve rasyonel aklın dışında çıktığından, modern bir perspektiften deliliği/çılgınlığı, anormalliği, epistemik ötekiyi temsil etmektedir. Devrim, Batılı politik rasyonalizme ve tarih tasavvuruna meydan okuyarak onları tarihselleştirmekte ve yerelleştirmektedir.

Foucault'nun devrime ilişkin yorumları açıkça bir Avrupalının yorumları olmakla birlikte basitçe Avrupamerkezcilikle suçlanamaz. Tanığı olduğu şey(ler) onun entelektüel ilgilerini derinden etkilemiş ve eserinin tematik dönüşümüne etki etmiştir. Bir kısım içsel gerilimlere rağmen o, söz konusu yazılarda İran'1 ve İslam'1 salt sabit bir metin olarak değil, yaşam pratiği, öznellik oluşturucu bir bilinç olarak okur. Devrimin dinamiğine odaklanarak oryantalizm Müslümanların değişmediği şeklindeki merkezi temasını aşmaya çalışır. Devrimle “oluş”a geleni Batılı kavramların içine sığdırma ya da damgalamak yerine, bu yeni fenomeni anlamlandırmak için yeni kavramlar inşa etmeye çalışır.

\section{Kaynakça}

Afary, Janet \& Kevin B. Anderson. Foucault ve Iran Devrimi: Toplumsal Cinsiyet ve İslamcılığın Ayartmaları (Çev. Mehmet Doğan), İstanbul: Boğaziçi Üniversitesi Yayınevi, 2012.

Almond, Ian., "The Madness of Islam: Foucault's Occident and the Revolution in Iran", Radical Philosophy 128, 2004, s. 12-22.

Bernauer, James. "Foucault's philosophy of Religion", in Michel Foucault and Theology (Edited by J. Bernauer and J. Carrette), Aldershot: Ashgate, 2004, s. 77-98. 
Carrette, Jeremy R. Religion and Culture: Michel Foucault. New York: Routledge, 1999.

Carrette, Jeremy.R.. Foucault and Religion. London: Routledge, 2000.

Diken, Bülent. İsyan, Devrim, Eleştiri: Toplum Paradoksu, (Çev. Can Evren), İstanbul: Metis Yayınları, 2013.

Eribon, Didier, Michel Foucault, (Çev. Şule Çiltaş), İstanbul: Ayrıntı Yayınlar1, 2012.

Foucault, Michel. “Ayaklanma Faydasız Mı?”, Entelektüelin Siyasi İşlevi, (Çev. Işık Ergüden, Osman Akınhay, Ferda Keskin), İstanbul: Ayrıntı Yayinlar1, 2000, 297-302.

Foucault, Michel. "İran Ayaklanmasının Efsanevi Önderi”, Janet Afary \& Kevin B. Anderson, Foucault ve Iran Devrimi: Toplumsal Cinsiyet ve İslamcılı̆̆ın Ayartmaları, (Çev. Mehmet Doğan), İstanbul: Boğaziçi Üniversitesi Yayınevi, 2012, s.

Foucault, Michel. "İran: Ruhsuz Dünyanın Ruhu”, Tezkire, Sayı: 2, Şubat-Mart 1992. s,

Foucault, Michel. "İranlılar Ne Düşlüyor?”, Janet Afary \& Kevin B. Anderson, Foucault ve Iran Devrimi: Toplumsal Cinsiyet ve İslamcılı̆̆ın Ayartmaları, (Çev. Mehmet Doğan), İstanbul: Boğaziçi Üniversitesi Yayınevi, 2012, s. 258-266.

Foucault, Michel. "İslam Denen Barut Fiçısı", Janet Afary \& Kevin B. Anderson, Foucault ve Iran Devrimi: Toplumsal Cinsiyet ve İslamcıllğın Ayartmaları, (Çev. Mehmet Doğan), İstanbul: Boğaziçi Üniversitesi Yay1nevi, 2012, s. 302-304.

Foucault, Michel. "İdeal Adalet mi, Sınıf mücadelesi mi?" (Michel Foucault-Noam Chomsky söyleşisi). Kendini Bilmek, Michel Foucault içinde (Çev. Gül Çağalı Güven), İstanbul: Om yayınevi. 1999. s. 154-159.

Foucault, Michel. "Şah Yüzyıl Geç Kaldı”, Entelektüelin Siyasi Iş̧levi, (Çev. Işık Ergüden, Osman Akınhay, Ferda Keskin), İstanbul: Ayrıntı Yayınları, İstanbul, 2000, 288-291.

Foucault, Michel. "Tahran: Şaha Karşı İnanç", Janet Afary \& Kevin B. Anderson, Foucault ve Iran Devrimi: Toplumsal Cinsiyet ve İslamcılı̆̆ın Ayartmaları, (Çev. Mehmet Doğan), İstanbul: Boğaziçi Üniversitesi Yayı- 
nevi, 2012, s. 252-258.

Foucault, Michel. "Başbakan Mehdi Bezirgân'a Açık Mektup”, Janet Afary \& Kevin B. Anderson, Foucault ve Iran Devrimi: Toplumsal Cinsiyet ve İslamcılığın Ayartmaları, (Çev. Mehmet Doğan), İstanbul: Boğaziçi Üniversitesi Yayınevi, 2012, s. 327-330.

Foucault, Michel, “ İktidar ve Bilgi”, İktidarın Gözü, (Çev. Işık Ergüden), İstanbul: Ayrıntı Yayınları, 2003, s. 167-184.

Foucault, "Michel Foucault ile Söyleşi: Mayıs "68 Boyunca "Sözcükler" ile "Şeyler” Arasında" Cogito, sayı, 14, 1998, s. 126-130.

Foucault, “Aydınlanma nedir?” Özne ve İktidar, (Çev. Işık Ergüden, Osman Akınhay, Ferda Keskin), İstanbul: Ayrıntı Yayınları, 2000, s. 162-172.

Foucault M., “Anti-Oedipus'a Önsöz”, Entelektüelin Siyasi Işslevi (Çev. Işsı Ergüden, Osman Akınhay, Ferda Keskin), İstanbul:Ayrıntı Yayınları, 2005, s. 54-58.

Ghamari-Tabrizi, Behrooz. "When Life Will No Longer Barter Itself: In Defense Of Foucault On The Iranian Revolution." in A Foucault for the 21st Century: Governmentality, Biopolitics and Discipline in the New Millenium, edited by S.Binkly and J. Capetillo. New Castle, UK: Cambridge Scholars Publishing, 2012, s. 271-292.

Khatami, Mahmoud, "Foucault on The Islamic Revolution of Iran", Journal of Muslim Minority Affairs, Vol. 23, No. 1, 2003, s.121-125.

Leezenberg, M. "Michel Foucault on the Islamic Revolution in Iran". In Cultural History after Foucault, edited by J. Neubauer. New York: Transaction Publishers, 1999, s. 63-82.

McCall, Corey. "Foucault, Iran, and the Question of Religious Revolt," International Studies in Philosophy, 40.1, 2008.

Mendieta, E. 'Spiritual Politics and Post-secular Authenticity: Foucault and Habermas on post-metaphysical religion', in Gorski, P., Kim, D., Torpe, J. (eds) The Post-Secular in Question: Religion in Contemporary Society. New York: NYU Press, 2012, s. 307-334.

Stauth, Georg. "Revolutions In Spiritless Times. An Essay On Michel Foucault's Enquiries Into The Iranian Revolution." International Sociology, 6 (3), 1991, s. 259-280. 
Versieren, Jelle and Brecht de Smet, "The Passive Revolution of Spiritual Politics: Gramsci and Foucault on Modernity, Transition and Religion" Ed. David Kreps, Gramsci and Foucault : a reassessment, Ashgate Publishing, 2015, s. 111-129. 